\title{
PSYCHOLOGICAL FACTORS OF EMOTIONAL DISADAPTATION OF ELDERLY PEOPLE
}

\author{
Inna Guryanova, $\mathrm{PhD}$ in Education \\ Alexander Soldatchenko, $\mathrm{PhD}$ in Education \\ Nosov Magnitogorsk State Technical University - NMSTU, \\ Magnitogorsk, Russia \\ Alex Sander da Silva \\ Universidade do Extremo Sul Catarinense - UNESC, \\ Criciuma, Brazil
}

\begin{abstract}
People of old age do face a number of difficulties (the ceasing work activity, the loss of near relatives, the emotional, financial and functional dependence on other people, etc.), which drastically change their habitual life style and lead to emotional disadaptation.
\end{abstract}

Key words: aging, types of aging, the elderly, old age people, emotional disadaptation, temporal disadaptation, situational disadaptation, refractory disadaptation.

Resumo: As pessoas de idade avançada fazer enfrentam uma série de dificuldades (a atividade de trabalho cessação, a perda de parentes próximos, a dependência emocional, financeira e funcional em outras pessoas, etc.), que mudar drasticamente seu estilo de vida habitual e levar a disadaptation emocional.

Palavras-chave: Tipos de envelhecimento, os idosos, as pessoas de idade avançada, inadaptação emocional,inadaptação temporal, inadaptação situacional, inadaptação em refratários.

Criar Educação, Criciúma, v. 6, ํo1, julho/novembro 2016.- PPGE - UNESC 
Being the final stage in the ontogenesis, aging is a natural irreversible process. It is absolutely different from preceding stages. One person's life undergoes the considerable changes because aging entails physiological, psychological and social alterations. These changes make an aging person facing a great number of different problems. Emotional disadaptation can be viewed as one of them. Those strata of society, which due to some objective or subjective reasons, cannot adapt by themselves, without assistance, experience disadaptation problems. The problem of disadaptation becomes particularly urgent for elderly people whose ability for readaptation is drastically reduced by social, psychological and medical factors. Helping these people is one of the main areas of social workers and psychologists' activity. The methods and means of maintaining elderly people's ability to lead an active life remain one of the burning issues in modern scientific research.

The peculiarities of disadaptation of elderly people who find themselves in difficult life situations as well as psychological factors encouraging its development were studied both by foreign (A. Maslow, C. Rogers, S. Freud, E. Fromm, K. Horny, K. Jung at al.) and Russian (V.A. Abramov, J.A. Alexandrovsky, S.A. Badmaev, L.S. Vygotsky, A.N. Leontyev, A.E. Lichko, A.K. Naprienko, S.L. Rubinstein at al.) psychologists.

Despite different meanings of the term "disadaptation", existing in modern science due to various approaches to the phenomenon, the same psychological parameters are considered its determining factors. Different researchers studying disadaptation pointed out the same psychological characteristic features (such as psychophysiological, individual, personal, behavioral, notional and motivational) which determine its fundamental nature.

Radical changes in the person's life and state caused by aging make him accommodate himself/herself to new conditions of life, bringing up the problem of adaptation to these environmental conditions.

Characteristic features and changes, which are peculiar to the old age and aggravated by retirement and ceasing work activity, can be classified according to three spheres.

1. The difficulties in acquiring new knowledge and notions, in adaptation to unforeseen contingencies arise in the intellectual sphere. A vast variety of circumstances can present a difficulty to elderly people. Some of them could have been overcome with rela-

Criar Educação, Criciúma, v. 6, nº1, julho/novembro 2016.- PPGE - UNESC 
tive ease in their young life (for example moving into a new house or a flat, disease, a sick relative or a friend, etc.). Others, especially if not encountered before, are difficult to cope with (for example the death of the spouse, the loss of ability to move freely, total of partial loss of vision, etc.).

2. The following difficulties can be observed in the emotional sphere: uncontrolled intensification of affective reactions (for example an intense nervous excitement or agitation) with a tendency to causeless sadness and frequent tearfulness.

3. The moral sphere is characterised by their refusal to accommodate themselves to the new moral code, customs, behavioural patterns, sharp criticism of these codes, customs and patterns.

A person faces new challenges in his/her old age. Eric Ericson believes that the main alternative of the period is a choice between integration and despair. That is when a person becomes mature he/she either achieves the integrity of his/her ego, which demonstrates itself in choosing and accepting his/her own way along the paths of life and acquiring wisdom, or gives himself/herself up to despair. In such a case the person is seized by fear of death; he/she also becomes aware that he/she did not live his/her life the way he/she wanted to live it. This awareness results in emotional disadaptation.

In scientific literature the term "emotional disadaptation" is defined as "the condition caused by chronic emotional strain, manifesting itself in a person's behaviour, temporal deterioration of all metal functions (from their normal level of development) due to the accumulation of physiological nervous exhaustion and emergence of symptoms of pseudoadaptive behaviour (neurological symptoms)" [9].

There are objective and subjective symptoms of disadaptation. The objective symptoms are the changes in a person's behaviour in a social sphere, inadequacy of his/her social functions, pathological transformation of his/her behaviour.

The subjective symptoms are psycho-emotional deviations varying from negative feelings to psychopathological syndromes. The state of a psychological impasse can also be viewed as a subjective symptom. This state is a result of a long-lasting conflict (either internal or external) and a lack of adaptive mechanisms which can help to overcome it.

There are different psychological, social and economic reasons for emotional disadaptation of elderly people. The most important among them are the following:

Criar Educação, Criciúma, v. 6, n¹, julho/novembro 2016.- PPGE - UNESC 
- the ceasing of work activity, - the reduction of personal contacts, - a reduction of income,

- the change of social roles, - an adaptation to new socio-economic conditions, - the change of living conditions, - the reduction of intellectual and physical abilities of an organism, - self-confidence deficit, - the mechanisms the person choses to cope with difficult situations in his/her life, etc.

It is difficult for elderly people to adapt themselves to constantly changing socioeconomic conditions. Many of them have such low incomes that they cannot satisfy their needs in medical care, accommodation, education, culture, etc. In this case, elderly people find themselves outside of the society. They are, in a sense, ousted from the society; it leads to the lowering their social identity. According to K. V. Rubchevsky the phenomenological characteristics of social identity deficit are:

1) the refusal to assume such essentials of social functioning as social duties and social responsibility; 2) a high level of social anxiety, involving social immaturity and indefiniteness of social status; 3 ) a tendency for conformal forms of social functioning; 4) the ego-centration and social self-isolation [8, p. 16].

All abovementioned characteristics are often found among elderly people and contribute to their emotional disadaptation.

A. A. Nalchadzhan in the work "Socio-psychic Adaptation of a Person" points out the following types of disadaptation: - temporal disadaptation (imbalance between a personality and its environment, resulting in a person's adaptive activity);

- stable situational disadaptation (a lack of personal adaptive mechanisms, the presence of desire but inability to adapt him/herself. This often happens to the group members who are not accepted by the group. This may result in an adoption of a defence complex, involving an illusory perception of the person's position in the group;

- general stable disadaptation (the state of constant frustration, which triggers pathological defence mechanisms, causing neuroses and psychoses) [7].

The disadaptation type of a particular person can be diagnosed according to the chosen mechanism of coping with difficult life situations or coping strategies.

Igor Kon, Russian philosopher, psychologist, and sexologist, classifies types of senility (coping strategies) according to the characteristic activity.

Criar Educação, Criciúma, v. 6, nº1, julho/novembro 2016.- PPGE - UNESC 
1. The first type is an active, creative senility. People, quitting their jobs, continue to take an active part in social life. They take life with both hands as it comes and enjoy it to the full, without feeling inferior or handicapped.

2. The second type of senility is also characterised by a good social and psychological adaptation. Although people direct their energy mainly to settling down in life, making their life more comfortable: material welfare, rest and recreation, self-education - everything they could not find time for before.

3. Women mainly belong to the third type. They commit themselves to their families. They have no time to be depressed or bored, yet their level of satisfaction in life is lower than that of the first and the second type.

4. People, whose purpose of life is a healthy life-style and promotion of health, constitute the fourth type. On the one hand, such a purpose stimulates various activities and gives satisfaction to them, on the other hand, this sort of people tends to exaggerate the importance of their real diseases and pseudomaladies [4].

I. Kon describes the above-mentioned types of senility as successful types. He also points out negative disadaptive types. Aggressive chronic grumblers, dissatisfied with their lives and state of affairs, criticising everyone and everything except themselves, belong to this type. Lonely sad losers, disappointed in themselves and their life, constitute another type of negative senility. They blame themselves for real and imaginary opportunities they have missed. If the scenario follows this pattern, an elderly person becomes emotionally disadaptive.

O.V. Krasnova believes that there are three types of senility: "happy", "unhappy" and psychopathological one. "Happy" senility is characterised by such traits as calmness, wisdom, enlightenment, quietism and composure. The so-called "unhappy" senility implies the rise of the level of personal anxiety, abnormal anxiety concerning the state of physical health as well as fears and doubts about trifles, diffidence, uncertainty about the future. These people are sure that their life has lost its meaning and they fail to find a new one; they constantly think about imminent death [6].

Based on the analysis of literary sources and the results of our own research we came to the conclusion that emotional disadaptation in old age is mainly influenced by the undermentioned factors.

Criar Educação, Criciúma, v. 6, nº1, julho/novembro 2016.- PPGE - UNESC 
1. Specific status of old people in the family. Old people lacking energy, stamina and vitality they used to have in their youth more than ever need a family (or a circle of close friends), which help them overcome the hardships of life. The way old people feel in an extended family (consisting of several generations) is often determined by the existing atmosphere which can be friendly or hostile. How duties are allocated in the family and the extent to what old people are included in this process also influence the way old people feel in the family. The following reasons, contributing to emotional disadaptation of old people in an extended family, should be mentioned: lack of respect from other family members; ignoring old people's interests; exploitative treatment of the elderly; grown-up children who refuse to do their duties to their elderly parents.

2. Conflicts as a source of emotional disadaptation in old age. At this period of life people face different conflicts. The most common one is an interpersonal conflict. It arises in dyads "mother - daughter", "mother - son", "father - daughter", "father - son". As a rule, the parties come into conflict with each other because one of them is not ready to swap roles. For example, an old person, who has no leverage to influence his grown-up child, tries to maintain his parental authority exerting constant pressure on his child without being aware that he himself needs to be taken care of. Another scenario is when grown-up children distance themselves from their parents, gradually lose contacts with them, demonstrating a separation or remoteness in relationship.

3. Social status of an old person. A change in social status in old age is mainly caused by retirement (ceasing or limiting work activity), transformation of sense of values, way of life and communication, as well as socio-economic condition, peculiarities in selfperception and perception of the others. Reconsideration of changes in life and social status results in the fact that the person is either, in general, satisfied with the current situation being inwardly ready for it or experiences deep emotional anxiety, feeling of dissatisfaction, annoyance and disappointment because nothing can be reverted or changed.

4. Both men and women feel lonely. Real subjective state of loneliness typically occurs together with the symptoms of mental disorders associated with negative emotions. For example, some people complain of sense of sorrow and depression the others say that they feel fear and anxiety, the third speak about grief and wrath.

Criar Educação, Criciúma, v. 6, nº1, julho/novembro 2016.- PPGE - UNESC 
Social contacts with friends and neighbours are more important for their wellbeing than contacts with relatives. These contacts help build up old people's sense of selfesteem and self-respect. They demonstrate that old people are needed and respected.

5. Limitations of old people's vital activity problematic are an urgent and complicated. Many members of society, who turned old age, have to give up their habitual social roles and statuses due to a number of reasons. This, in its turn, leads to the destruction of a person's life style, reduction of personal contacts and sharp decrease in other social opportunities.

6. Stereotypes of senility. There are both positive and negative attitudes to old age. On the one hand, old age is the epitome of wisdom and full life, which was not dissipated. On the other hand, the problems brought about by fading of vitality cause negative reactions. The mentality of population at large, including the oldest people, is, to a certain extent, characterised by ageism.

If we learned to prolong life of the majority of people to extreme old age, we should also learn how to change stereotypes and attitudes to old age among the elderly, their relatives and the people around them. The microcosm of man is his mind, and this is the mentality we have little known. The psychologists and philosophers are saying that psyche (or a microcosm of the person) must be streamlined both inside of him/herself, and in external mental life space [2, 49].

Based on the carried out analysis it can be concluded that psychological work with elderly people should be aimed at encouraging them to play an active social roles, to communicate with other people, to support a positive self-actualization, peace of mind, activity and enjoyment of life. Besides, psychological and social services should fulfill an important task of changing the attitude to elderly people in modern society.

Criar Educação, Criciúma, v. 6, ำ1, julho/novembro 2016.- PPGE - UNESC 


\section{References:}

1. Guryanova, I.V. Training of university students for work with elderly people : cand. sci. diss. (Pedagogics) 13.00.08 / Magnitogorsk State University, 2006.

2. Guseva, L.G., Buzunova, L.G. Education and spiritual world as a basis for the healthy life strategy / In «Social sciences and public health: theoretical approaches, empirical researches, practical decisions». The proceedings of the 4th internatioal scientific conference on April 20-21, 2014. // Prague :Vedecko vydavatelske centrum "Sociosfera-CZ", 2014, Pp. $42-49$.

3. Buzunova L.G., Guseva, L.G., Razumova E. et.al. Psychological factors of the formation of a functional system of the woman / Actual research problems in social psychology. - Magnitogorsk: NMSTU Press, 2013. - 190 p. Pp. 30-71.

4. Kon, I.S. Searching for your own self : Personality and Self-consciousness. Moscow : Politizdat, 1984. - $151 \mathrm{p}$.

5. Kuznetsova, L. E. Psychological peculiarities of mental disadaptation of elderly people living out of family [Text] / L.E. Kuznetsova, V.P. Chebotaryev // Young Scientist. - 2014. - \# 5. - Pp. 452-455.

6. Maksimova, S.G. Socio-psychological aspect of disadaptation of elderly people and people of an old age / S.G. Maksimova // Clinical Gerontology. - 2000. - \# 6. Pp. 58-63.

7. Nalchadzhan, A.A. Socio-psychic adaptation of a personality (Forms, Mechanisms and Strategies) / A.A. Nalchadzhan // Yerevan: Publishing House of the Academy of Sciences of the Soviet Socialist Republic of Armenia. - 1988. - $268 \mathrm{p}$.

8. Rubchevsky, K.V. Forms of undergoing personality's socialization / K.V. Rubchevsky. - Moscow : Prosveshchenie, 2002. - 122 p.

9. Social Gerontology: Reference Dictionary / author-compiler N.F. Basov. - Moscow : Socio-technological Institute, 2000. - 242 p.

Authors:

\section{Inna Guryanova}

$\mathrm{PhD}$ in Education, Associate Professor

Department of Social Work, Psychological and Pedagogical Education,

Criar Educação, Criciúma, v. 6, ำ1, julho/novembro 2016.- PPGE - UNESC 
Institute of Pedagogy, Psychology and Social Work

Nosov Magnitogorsk State Technical University

Magnitogorsk, Russian Federation

\section{Alexander Soldatchenko}

$\mathrm{PhD}$ in Education, Associate Professor

Department of Foreign Languages for Professional Communication, Institute of History, Philology and Foreign Languages,

Nosov Magnitogorsk State Technical University

Magnitogorsk, Russian Federation

Criar Educação, Criciúma, v. 6, ำ1, julho/novembro 2016.- PPGE - UNESC 